\title{
RELIABILITY VERIFICATION OF AN EXISTING REINFORCED CONCRETE SLAB
}

\author{
Milan HOLICKÝ1, Karel JUNG ${ }^{2}$ \\ ${ }^{1}$ Department of Structural Reliability, Klokner Insitute, CTU in Prague, Šolínova 7, Prague, Czech Republic \\ 2 Department of Structural Reliability, Klokner Insitute, CTU in Prague, Šolínova 7, Prague, Czech Republic \\ $\underline{\text { milan.holicky@cvut.cz, karel.jung@,cvut.cz }}$
}

DOI: 10.31490/tces-2018-0009

\begin{abstract}
The submitted contribution provides background information on the principles accepted in the CEN Technical Specification (TS). The application of the verification methods provided in the TS is clarified by an assessment of a reinforced concrete precast panel. The panel provides insufficient resistance in comparison to that required by Eurocodes for design of new structures. The critical comparison of the reliability levels indicated by Eurocodes, the assessment value method, and fully probabilistic approach demonstrates the benefits gained by applying the principles of the TS. While the partial factors recommended in Eurocodes leads to a negative result the assessment value method and the probabilistic method indicate sufficient structural reliability.
\end{abstract}

\section{Keywords}

Existing structures, partial factors, assessment values, probabilistic assessment.

\section{Introduction}

The CEN Technical Specification (TS) on assessment of existing structures are related to the probabilistic concepts and fundamental requirements of the EN Eurocodes. This document concerns all types of buildings, bridges and construction works, including geotechnical structures, exposed to all kinds of actions. The TS contains requirements, general framework of assessment, data updating, structural analysis, formats of verification, consideration of past performance, interventions, and annexes (flowchart, time-dependent reliability, assessment of heritage structures).

The following example concerns an existing building constructed in 1970 that is to be renovated and a new reliability assessment is required. The presented assessment is limited to a simply supported reinforced concrete panel (a prefabricated hollow core floor panel) of the span $L=6 \mathrm{~m}$ and the total thickness $0.19 \mathrm{~m}$. Width of the panel is $2.4 \mathrm{~m}$.

The panel should be exposed to additional permanent load due to newly designed floor surface. The following requirements are specified: the remaining working life is 50 years, the target reliability index related to the reference period of 50 years is $\beta_{\mathrm{t}}=3.8$. The target reliability can be adjusted to the actual economic and societal conditions.

Table 1 indicates expected characteristic values of actions specified in accordance with EN 1991, of the load effect $E$ (the mid-span point bending moment) and of the corresponding current capacity of the panel $R$ taken from relevant background documentation.

Tab.1: Characteristic values of actions and resistance

\begin{tabular}{|l|c|c|c|}
\hline & $\begin{array}{c}\text { Permanent } \\
\text { load } \boldsymbol{g}\left[\mathrm{kN} / \mathrm{m}^{2}\right]\end{array}$ & $\begin{array}{c}\text { Imposed load } \boldsymbol{q} \\
{\left[\mathrm{kN} / \mathrm{m}^{2}\right]}\end{array}$ & $\begin{array}{c}\text { Panel } \\
\text { resistance } \boldsymbol{R} \\
{[\mathrm{kNm}]}\end{array}$ \\
\hline $\begin{array}{l}\text { Characteristic } \\
\text { values }\end{array}$ & 6.264 & 1.50 & 43.23 \\
\hline $\begin{array}{l}\text { Characteristic } \\
\text { total actions }\end{array}$ & 7.764 & - \\
\hline $\begin{array}{l}\text { Characteristic } \\
\text { values } E_{\mathrm{k}} \text { and } \\
R_{\mathrm{k}}[\mathrm{kNm}]\end{array}$ & 34.94 & 43.23 \\
\hline
\end{tabular}

It follows from Tab. 1 that the characteristic load effect $E_{\mathrm{k}}$ is less than the characteristic resistance $R_{\mathrm{k}}$. However, the characteristic values of the actions $E_{\mathrm{k}}$ and resistance $R_{\mathrm{k}}$ alone cannot be used to assess structural safety. The inequality $E_{\mathrm{k}}<R_{\mathrm{k}}$ indicates only a possible safety margin. Submitted study shows that the panel that does not comply with the requirements given in EN 1990 [1, 2], which are however valid for design of new structures. More sophisticated verification approaches indicated in the following text seem to be effective. 


\section{Assessment using partial factors}

\subsection{Partial factors in EN 1990}

This simple assessment approach does not require any specific statistical procedure; however, it often leads to unfavourable assessment results. Partial factors recommended in EN 1990. Corresponding to the target reliability index $\beta_{\mathrm{t}}=3.8$ and related to the reference period of 50 years are indicated in Tab. 2 .

Tab.2: Partial factors and assessment values of actions and resistance

\begin{tabular}{|l|c|c|c|}
\hline & $\begin{array}{c}\text { Permanent } \\
\text { load } \boldsymbol{g}\left[\mathrm{kN} / \mathrm{m}^{2}\right]\end{array}$ & $\begin{array}{c}\text { Imposed load } \boldsymbol{q} \\
{\left[\mathrm{kN} / \mathrm{m}^{2}\right]}\end{array}$ & $\begin{array}{c}\text { Panel } \\
\text { resistance } \boldsymbol{R} \\
{[\mathrm{kNm}]}\end{array}$ \\
\hline $\begin{array}{l}\text { Characteristic } \\
\text { values }\end{array}$ & 6.264 & 1,5 & 43.23 \\
\hline Partial factors & 1.35 & 1.5 & 1.15 \\
\hline $\begin{array}{l}\text { Assessment } \\
\text { values }\end{array}$ & 8.456 & 2.25 & 37.59 \\
\hline $\begin{array}{l}\text { Total } \\
\text { assessment load }\end{array}$ & \multicolumn{2}{|c|}{10.706} & - \\
\hline $\begin{array}{l}\text { Assessment } \\
\text { values } E_{\mathrm{d}} \text { and } \\
R_{\mathrm{d}}[\mathrm{kNm}]\end{array}$ & \multicolumn{2}{|c}{48.18} & 37.59 \\
\hline
\end{tabular}

The resistance $R$ is predominantly dependent on reinforcement, thus the partial factor for $R$ is 1.15 .

\subsection{Adjusted partial factors}

The partial factors may be adjusted considering the coefficients of variation assessed for the prefabricated structure. The required target reliability index $\beta_{\mathrm{t}}=3.8$ and sensitivity factors $\alpha_{E}=-0.7$ and $\alpha_{R}=0.8$ are accepted.

Tab. 3 indicates all the necessary data for basic variables $g, q$ and $R$, the adjusted partial factors accounting for model uncertainties and dimensional variation and the resulting assessment values of the load effect $E_{\mathrm{a}}$ and resistance $R_{\mathrm{a}}$.

Coefficients of variation $V$ indicated in Tab. 3 are assessed taking into account available data, actual conditions of the prefabricated reinforced concrete panel and also the relevant model uncertainty (if applicable) using a general formula [10]

$$
V=\sqrt{V_{i}^{2}+V_{g e o}^{2}+V_{u n c}^{2}}
$$

Here $V_{i}$ denotes the coefficient of variation of the relevant basic variable $i, V_{\text {geo }}$ denotes the coefficient of variation of the relevant geometry and $V_{\text {unc }}$ denotes the coefficient of variation of the model uncertainty. The coefficient of variation of the resistance $R$ is predominantly dependent on reinforcement. The adjusted partial factors are then determined using the procedure described in EN 1990 ([1], [2]). Adjusted partial factors for the resistance $R$ are indicated in Annex 1. The distributions assumed for the basic variables $g, q$ and $R$ are taken from literature (for example [3], [4] and [5]). The resulting coefficients of variation and partial factors are relatively small but close to those used in original design. However, similarly as in the previous case of partial factors recommended in EN 1990 [1], the total load effect $E_{\mathrm{a}}=41.87 \mathrm{kNm}$ is greater than the resistance $R_{\mathrm{a}}=39.30 \mathrm{kNm}$. Consequently, using the adjusted partial factors, the structure is still not acceptable

Tab.3: Adjusted partial factors and assessment values of actions and resistence

\begin{tabular}{|c|c|c|c|}
\hline & $\begin{array}{c}\text { Permanent } \\
\operatorname{load} \boldsymbol{g}\left[\mathrm{kN} / \mathrm{m}^{2}\right]\end{array}$ & $\begin{array}{c}\text { Imposed load } \boldsymbol{q} \\
{\left[\mathrm{kN} / \mathrm{m}^{2}\right]}\end{array}$ & $\begin{array}{c}\text { Panel } \\
\text { resistance } \boldsymbol{R} \\
{[\mathrm{kNm}]}\end{array}$ \\
\hline $\begin{array}{l}\text { Characteristic } \\
\text { values }\end{array}$ & 6.264 & 1.5 & 43.23 \\
\hline $\begin{array}{l}\text { Coefficients of } \\
\text { variation } V\end{array}$ & 0.05 & 0.30 & 0.06 \\
\hline $\begin{array}{l}\text { Assumed } \\
\text { distribution }\end{array}$ & Normal & Gumbel & Lognormal \\
\hline $\begin{array}{l}\text { Adjusted partial } \\
\text { factors } \gamma\end{array}$ & 1.15 & 1.4 & 1.1 \\
\hline $\begin{array}{l}\text { Assessment } \\
\text { values }\end{array}$ & 7.204 & 2.10 & 39.30 \\
\hline $\begin{array}{l}\text { Total } \\
\text { assessment load }\end{array}$ & \multicolumn{2}{|c|}{9.304} & \\
\hline $\begin{array}{l}\text { Assessment } \\
\text { values } E_{\mathrm{a}} \text { and } R_{\mathrm{a}} \\
{[\mathrm{kNm}]}\end{array}$ & \multicolumn{2}{|c|}{41.87} & 39.30 \\
\hline
\end{tabular}

This slightly more complicated assessment method due to the specification of the partial factors needs a statistical technique. When adjusting the partial factors of all the basic variables, it is necessary to determine statistical characteristics, coefficients of variation $V$ and to specify an appropriate probability distribution. Commonly the normal distribution is used for permanent actions, the Gumbel or lognormal distribution is applied for variable actions and the lognormal distribution for resistance parameters. However, to make a correct decision concerning the type of distribution, available data are to be statistically evaluated. In particular, the third moment characteristic of data (the skewness or asymmetry) may be very effective to choose an appropriate distribution.

\section{Assessment value method}

The assessment value method follows the procedure indicated in following equation

$$
R_{\mathrm{a}}-E_{\mathrm{a}}>0, \Phi_{R}\left(R_{\mathrm{a}}\right)=\Phi\left(-\alpha_{R} \beta_{\mathrm{t}}\right), \Phi_{E}\left(E_{\mathrm{a}}\right)=\Phi\left(-\alpha_{E} \beta_{\mathrm{t}}\right)(2)
$$

assuming $\beta_{\mathrm{t}}=3.8$ (the required remaining working life 50 years) and sensitivity factors $\alpha_{E}=-0.7$ and $\alpha_{R}=0.8$ and $\Phi$ is the cumulative distribution function. To determine the assessment values $E_{\mathrm{a}}$ and $R_{\mathrm{a}}$ of $E$ and $R$, appropriate statistical characteristics of all the basic variables $X_{i}$ 
including their statistical distribution are needed. The assessment values are determined directly (as indicated in Annex 2) and no partial factors are needed. Table 4 indicates characteristics of the basic variables including the resulting load effect $E_{\mathrm{a}}$ and the resistance $R_{\mathrm{a}}$, the type of their statistical distribution and their assessment values.

Tab.4: Assessment value method

\begin{tabular}{|c|c|c|c|}
\hline & $\begin{array}{c}\text { Permanent } \\
\operatorname{load} \boldsymbol{g}\left[\mathrm{kN} / \mathrm{m}^{2}\right]\end{array}$ & $\begin{array}{c}\text { Imposed load } \boldsymbol{q} \\
{\left[\mathrm{kN} / \mathrm{m}^{2}\right]}\end{array}$ & $\begin{array}{c}\text { Panel } \\
\text { resistance } \boldsymbol{R} \\
{[\mathrm{kNm}]}\end{array}$ \\
\hline $\begin{array}{l}\text { Characteristic } \\
\text { values }\end{array}$ & 6.264 & 1.5 & 43.23 \\
\hline The means & 6.264 & 0.9 & 48.00 \\
\hline $\begin{array}{l}\text { Coefficients of } \\
\text { variation }\end{array}$ & 0.05 & 0.3 & 0.06 \\
\hline $\begin{array}{l}\text { Standard } \\
\text { deviations }\end{array}$ & 0.313 & 0.27 & 2.88 \\
\hline $\begin{array}{l}\text { Assumed } \\
\text { distribution } \gamma\end{array}$ & Normal & Gumbel & Lognormal \\
\hline Ratios $x_{\mathrm{a}} / \mu$ & 1.1 & 2.30 & 0.85 \\
\hline $\begin{array}{l}\text { Assessment } \\
\text { values } x_{\mathrm{a}} \text { of } X\end{array}$ & 6.89 & 2.07 & 41.00 \\
\hline Total load & \multicolumn{2}{|c|}{8.96} & - \\
\hline $\begin{array}{l}\text { Assessment } \\
\text { values } E_{\mathrm{a}} \text { and } R_{\mathrm{a}} \\
{[\mathrm{kNm}]}\end{array}$ & \multicolumn{2}{|c|}{40.32} & 41.00 \\
\hline
\end{tabular}

In accordance with the assessment value method the load effect $E_{\mathrm{a}}=40.32 \mathrm{kNm}$ is less than the resistance $R_{\mathrm{a}}=41.00 \mathrm{kNm}, E_{\mathrm{a}}<R_{\mathrm{a}}$, and this method leads to a positive result: the structure is suitable. Often the assessment value methods provide more favourable conclusions concerning the reliability of existing structures than the common partial factor methods.

\section{Probabilistic method}

The probabilistic approach to verify the reliability of the assessed structure is based on appropriate limit state function indicated in Technical specifications (TS) [9]. This approach considers all basic variables $X_{i}$ as random variables described by appropriate probabilistic models. In the considered example three basic variables, $g, q$ and $R$ are considered as already described in the previous sections. Using the probabilistic methods, the reliability of a structure is analysed considering the limit state function $g\left(X_{i}\right)$ of the basic variables $X_{i}$. In the example of a floor panel having the span $L=6 \mathrm{~m}$ (taken by deterministic value), the limit state function has a simple form

$$
g\left(X_{i}\right)=R-(g+q) \times L^{2} / 8
$$

As indicated by following equation (6.5) in TS [9]

$$
P_{\mathrm{f}}=P\left\{g\left(X_{i}\right)<0\right\}<P_{\mathrm{ft}}
$$

Where $P_{\mathrm{f}}$ denotes failure probability and $P_{\mathrm{ft}}$ is the target probability of failure for a given reference period (e.g. one year). It is assumed that the structural failure occurs when the limit state function is negative (the resistance $R$ is insufficient), therefore when

$$
g\left(X_{i}\right)<0
$$

When the limit state function is positive, $g\left(X_{i}\right) \geq 0$ then the panel is assumed to be safe.

The utilization of the probabilistic approach usually requires the application of some software products (for example of COMREL [7] or VaP [8]). The required statistical data and appropriate probabilistic models of the basic variables related to the panel are indicated in Tab. 5 .

Tab.5: Probabilistic models of basic variables.

\begin{tabular}{|l|c|c|c|}
\hline $\begin{array}{l}\text { Assessment } \\
\text { method }\end{array}$ & $\begin{array}{c}\text { Permanent } \\
\text { load } \\
{\left[\mathrm{kN} / \mathrm{m}^{2}\right]}\end{array}$ & $\begin{array}{c}\text { Imposed } \\
\text { load } \\
{\left[\mathrm{Kn} / \mathrm{m}^{2}\right]}\end{array}$ & $\begin{array}{c}\text { Panel } \\
\text { resistance } \\
{[\mathrm{kNm}]}\end{array}$ \\
\hline $\begin{array}{l}\text { Characteristic } \\
\text { value }\end{array}$ & 6.264 & 1.5 & 43.23 \\
\hline The mean & 6.264 & 0.9 & 48.00 \\
\hline $\begin{array}{l}\text { Coefficient of } \\
\text { variation }\end{array}$ & 0.05 & 0.3 & 0.06 \\
\hline $\begin{array}{l}\text { Standard } \\
\text { deviation }\end{array}$ & 0.31 & 0.27 & 2.88 \\
\hline $\begin{array}{l}\text { Inherent } \\
\text { skewness }\end{array}$ & 0 & 1.14 & 0.18 \\
\hline Distribution & Normal & Gumbel & Lognormal \\
\hline
\end{tabular}

Note that the Gumbel distribution has relatively high skewness (1.14), which may be greater than the actual skewness of the imposed load $q$. Then the three parameter lognormal distribution may be more suitable. Accepting the Gumbel distribution of $q$, the assessed failure probability of the panel is $P_{\mathrm{f}}=1.3 \times 10^{-5}$ and the reliability index $\beta=-\Phi_{u}^{-1}\left(P_{\mathrm{f}}\right)=4.20$. These results may be slightly conservative. When the imposed load $q$ is described by the lognormal distribution having a lower skewness $(0.90)$, the obtained reliability index $\beta$ will be slightly greater $(\beta=4.25)$.

\section{Risk assessment method}

The risk assessment method can be an effective approach in case of an important structure when the resistance is insufficient and structural or operational interventions appear to be needed. Then the procedure of risk-informed decision making, as indicated in Clause 7 of ISO 2394 [6], can be very useful. In the case of a minor structure (as the assessed floor panel) when possible structural or operational interventions are considered (even when the structure seems to be acceptable but it is intended to increase the current reliability level) then instead of the risk assessment the cost optimization of possible interventions may be applied. A procedure of cost 
optimisation may be derived from the general risk assessment method.

\section{Conclusion}

The results of the panel assessment including recommended decisions based on the applied verification methods are indicated in following Tab. 6.

Tab.6: Results of the applied assessment methods.

\begin{tabular}{|l|c|c|c|c|}
\hline $\begin{array}{l}\text { Assessment } \\
\text { method }\end{array}$ & $\begin{array}{c}\text { Load } \\
\text { effect } \\
{[\mathrm{kNm}]}\end{array}$ & $\begin{array}{c}\text { Resistance } \\
{[\mathrm{kNm}]}\end{array}$ & $\begin{array}{c}\text { Reliability } \\
\text { index } \boldsymbol{\beta}\end{array}$ & Results \\
\hline $\begin{array}{l}\text { Partial factors } \\
\text { of EN }\end{array}$ & 48.30 & 37.59 & - & Negative \\
\hline $\begin{array}{l}\text { Adjusted partial } \\
\text { factors }\end{array}$ & 41.87 & 39.30 & $\begin{array}{c}\text { Assumed } \\
3.8\end{array}$ & Negative \\
\hline $\begin{array}{l}\text { Assessment } \\
\text { values }\end{array}$ & 40.32 & 41.00 & $\begin{array}{c}\text { Assumed } \\
3.8\end{array}$ & Positive \\
\hline $\begin{array}{l}\text { Probabilistic } \\
\text { method }\end{array}$ & - & - & $\begin{array}{c}\text { Assessed } \\
4.2\end{array}$ & Positive \\
\hline
\end{tabular}

It follows that the partial factor methods lead to negative results when both the partial factors recommended in Eurocodes and the adjusted partial factors obtained considering the index $\beta=3.8$ are applied. The assessment value method (when index $\beta=$ 3.8 is assumed to determine the assessment values) leads to a positive result. The probabilistic method indicates also a positive result as the resulting reliability index $\beta=$ 4.2 is greater than the required reliability level corresponding to the index $\beta=3.8$. Therefore, for the remaining working life of 50 years the considered panel seems to be sufficiently reliable.

This illustrative example of a floor panel may provide guidance to the assessment of a one-off structure, for example of a column or bridge elements. It should be emphasized that the actual conditions and available data concerning action and resistance variables should be always taken into account. When limited data are available only, then advanced statistical methods including data updating can provide valuable techniques. In general, the relevant target reliability level (index $\beta$ ) and sensitivity factors $\alpha_{E}$ and $\alpha_{R}$ should be re-examined. In some significant cases the risk assessment method indicated in Clause 6 of TS [9] and publications [4, 5] may be advisable. When possible structural or operational interventions are considered (to increase the current reliability level even when it seems to be acceptable), then the cost optimization of possible interventions may be applied.

\section{Acknowledgements}

This contribution has been developed at the Klokner Institute of the Czech Technical University in Prague, Czech Republic, as a part of the research project GAČR 16-11378S, "Risk based decision making in construction" and 16-04132S "Epistemic uncertainty of crack models in reinforced concrete structures" supported by the Czech Grant Agency.

\section{References}

[1] EN 19902002 Eurocode - Basis of structural design.

[2] prEN 19902017 Eurocode - Basis of structural design

[3] JCSS 2001 Joint Committee for Structural Safety. "Probabilistic Model Code", http://www.jcss.ethz.ch/

[4] HOLICKÝ, M. Reliability analysis for structural design. SUN MeDIA Stellenbosch, ZA, 2009. ISBN 978-1-920338-11-4, 199 pages.

[5] HOLICKÝ, M. Introduction to Probability and Statistics for Engineers, Springer-Verlag Berlin Heidelberg, New York, London, 2013. ISBN 978-3642-38299-4

[6] ISO 23942015 General Principles on Reliability for Structures.

[7] COMREL version 6.00. Software product RCP, Consulting Software, Germany.

[8] VaP Software product of PSP - Petschacher Software und Projektentwicklungs $\mathrm{GmbH}$, Austria.

[9] The Final Draft of Technical Specification Assessment of Existing Structures, M515 WG2.T1

[10] ČSN 7300382014 Hodnocení existujících konstrukcí - doplňující ustanovení pro navrhování

\section{About Authors}

Milan Holický was born in Tábor, Czech Republic. He received his engineering degree from CTU in Prague in 1965. His research interests include structural reliability.

Karel JUNG was born in Domažlice, Czech Republic. He received his M.Sc. from CTU in Prague in 2002. His research interests include risk analysis and structural reliability. 